\title{
TUNGIASIS IN SCHOOLCHILDREN IN CRICIÚMA, SANTA CATARINA STATE, SOUTH BRAZIL
}

\author{
Otenia Rosalba da Silva DAMAZIO(1) \& Marcos Vinicius da SILVA(2,3)
}

\begin{abstract}
SUMMARY
Tungiasis is a common parasitic skin disease in Brazil, caused by the flea Tunga penetrans. We conducted a cross-sectional study to evaluate the occurrence of infestation with T. penetrans in primary schoolchildren in Criciúma, Santa Catarina State (South Brazil). In total, 917 children (6-10 years) of 68 schools were included in the study (11\% of target population). Physical examination was followed by residential visits of those infested, to assess housing conditions and to interview the children's guardians. Of the 917 , $15(1.6 \%)$ children were infested with the parasite. The prevalence was twice as high in females (10 children - 2.2\%) as compared to males (five children $-1.1 \%$ ), but due to the low number of infested individuals, the difference was statistically not significant $(p=$ 0.18). The mean number of lesions found was 1.4 per child. One child presented bacterial superinfection. Of the 15 children infested, $10(66.7 \%)$ studied in schools built on pyritiferous soil. The families of 12 children (79.9\%) had been living in the area in which the study was conducted for less than eight years and were considered underprivileged families with the head of the household having a low education status. We conclude that in Criciúma tungiasis occurs in primary school children, but prevalence and parasite load are low.
\end{abstract}

KEYWORDS: Tunga penetrans; Tungiasis; Zoonosis; Parasitic skin disease; Public health, Brazil.

\section{INTRODUCTION}

Tungiasis is caused by the infestation with the female fleas, Tunga penetrans (LINNAEUS, 1758) and T. trimamillata (PAMPIGLIONE et al., 2003) $)^{38}$ (Siphonaptera: Tungidae); these ectoparasites are small fleas of about $1 \mathrm{~mm}$ in length. Both males and females are hematophagous but only the female penetrates into the dermis of the host causing intense inflammatory reaction, resulting in rash, itching, and pain ${ }^{29,30,32}$.

The natural habitat of the parasite are sandy and hot grounds, such as beaches and rural areas in tropical and sub-tropical regions. The fleas cannot jump high and therefore usually penetrate in the feet and paws of the hosts. There are various popular designations to the flea: in English-speaking countries it is named "Jigger"; in Brazil, "bicho-do-pé" or "bicho porco"; in the remnant of South American, "niguia, "pique" and "chica"; in some regions of Paraguay exclusively in Tupy Guarany, "tï" "These designations indicate that the tungiasis has been a common disease in many parts of the tropics.

The main hosts are humans, dogs, cats, pigs, and rats, among others $^{39}$. Tungiasis is common among low-income populations living in underprivileged communities in South and Central America, SubSahara areas and Seychelles Islands ${ }^{17}$. In these locations, heat, poor infra-structure, little or no attention given to preventive medicine and strong cultural values contribute to the endemic occurrence. In the countries located outside equatorial zones, sporadic cases of the disease have been reported in tourists, military expeditions and business people who travel to these areas ${ }^{4,6}$.

While in Brazil the disease occurs throughout the country, from the Amazon region to the South, it is not considered as a significant public health issue. Consequently, its prevalence is poorly known or neglected. Studies in some endemic areas have demonstrated overall prevalence among $16 \%$ and $55 \% \%^{1,3,6,20}$.

FELDMEIER et al..${ }^{14}$ have shown that the immunological response to tungiasis involves lymphocyte $\mathrm{T}$ Th1 response as well as lymphocyte $\mathrm{T}$ Th2 response, characterized by increase of Interferon- $\gamma$ (IFN- $\gamma$ ), tumor necrosis factor- $\alpha$ (TNF- $\alpha$ ) and low concentrations of Interleukin ( IL-4). EISELE et al. ${ }^{11}$, in histo-pathological research studies of skin damage of $T$. penetrans have shown that there is an intense peripheral inflammatory process with the presence of leukocytes, mastocytes, eosinophils, and hystiocytes. The pathological alterations of the epidermis are characterized by hyperplasia, parakeratosis, hyperkeratosis and spongiosis $^{19}$.

As the disease evolves, complications occur commonly, such as loss of fingernails, wounds, bacterial superinfection, and severe infestation leading to difficulty in walking and gripping. The lesions caused by $T$. penetrans are also a port of entry for Clostridium tetani, leading to tetanus 
in non-vaccinated patients, and gangrene by Clostridium perfingens which in some cases, requires amputation ${ }^{15,29}$.

Treatment of tungiasis is by surgical extraction of the flea under sterile conditions ${ }^{25}$. HEUKELBACH et al..${ }^{19}$ used solutions of ivermectin or metrifonate or thiabendazole, with decrease of the number of lesions. HEUKELBACH et al. $^{21}$ also used ivermectin, orally administered, and showed that ivermectin does not have any significant efficacy. While the options for treatment of tungiasis are limited, prophylaxis is still the best alternative in controlling the parasite ${ }^{16}$.

The purpose of this study was to establish the occurrence of tungiasis in elementary schoolchildren in the city of Criciúma.

\section{MATERIALS AND METHODS}

Study area and design: Criciúma is located in Santa Catarina State, Southeast Brazil. It has approximately $245 \mathrm{~km}^{2}$ and a population of 150,000 inhabitants. With average temperatures around $19.2{ }^{\circ} \mathrm{C}$ and annual rain falls of $1,475 \mathrm{~mm}^{3}$, Criciúma has a humid (mesotermic) climate. Criciúma is an industrial city ${ }^{27}$. The environment in Criciúma has been deteriorated by toxic residues from the coal industry. Many of these areas were sold and condominiums, kindergartens, schools, and theme parks were built.

According to the Secretary of Education, there were in total 69 public schools with 8,370 children aged $6-10$ years, in 2003. A pilot study was done with students of three randomly selected schools in April 2003. Schools from an underprivileged area, other in the central area, and other in the suburbs were chosen to study the occurrence of tungiasis. Because there was no prior information about the disease in Criciúma, based on the prevalence of tungiasis found in the pilot study (4\%), the sample size was estimated, considering $99 \%$ reliability and approximately $1.5 \%$ standard deviation.

The period of the year was chosen according to observations done by HEUKELBACH et al. ${ }^{23}$, which showed that the occurrence of tungiasis increases in the dry season. The same was perceived by OBENGUI ${ }^{37}$, in 1989, in Congo, Africa, where most cases occurred between the months of June and October, in the dry season.

Field study was conducted between October and December of 2003. The sample population was 917 children, who participated in the study, and who were physically examined, hands and feet, for tungiasis. Physical examination of children was performed followed by an interview with the legal guardian, using a structured questionnaire assessing demographic, socio-economic and behavioral variables. Home visits were made to those children diagnosed with tungiasis in order to evaluate the sanitary conditions and also to detect if other members of the families were infested as well.

Before the beginning of the study, meetings were held with teachers and parents in order to brief them about tungiasis, the objectives of the study, and other relevant information.

If tungiasis was diagnosed, the patient was sent to the Public Health Clinic to be treated according to standard procedures.
Ethical considerations: The study was developed according to the Helsinki Declaration of 1975, revised in 1983, and approved by the Ethical Committee of the University of South of Santa Catarina (Universidade do Sul de Santa Catarina). The children participated in the study only after obtaining written consent from their legal guardians; in addition, the Secretary of Education of Criciúma permitted us to perform the study.

Statistical analysis: The statistical analysis was done using the Epi 6.4/ Statistic for Windows and STATA 8.0. The chi-square and Fisher's exact tests were applied to compare relative frequencies.

\section{RESULTS}

A total of 917 children were examined. That reflects $10.9 \%$ of the target population. Of these, $454(49.5 \%)$ were female and $463(50.5 \%)$ male. The overall prevalence was $1.6 \%$ (15 infested) IC 95\% $=0.92 \%$ - 2.68\%, 10 (prevalence was 2.2\%) IC $95 \%=1.06 \%-4.01 \%$ were female and five (prevalence 1.1\%) IC 95\% $=0.35 \%-2.50 \%$ male $(p=$ $0.18)$. In total, 21 lesions were found in 15 individuals with a mean of 1.4 parasites per child. All lesions were localized on the feet. Secondary bacterial infection was diagnosed in only one child. The prevalence was significantly higher in the ages of eight and 10 years when compared to the other age groups $(p<0.001)$. Table 1 details prevalence stratified by age.

The distribution of the parasitism according to the school year was the following: five (33.3\%) students were in the first grade, six (40\%) in the second, one $(6.7 \%)$ in the third and three $(20 \%)$ in the fourth. In kindergarten children parasitism was not detected.

Out of the 69 schools in the municipality of Criciúma, 68 participated in the study, 13 (19.1\%) were located on pyritiferous soil. Out of the 15 children infected, $10(66.7 \%)$ studied in schools built on pyritiferous soil.

The period of residence in the municipality of Criciúma of families with infested children was as follows: four $(26.7 \%)$ resided for two or less years, five $(33.2 \%)$ between two and five years, three $(20.0 \%)$ between six and eight years, one $(6.7 \%)$ between nine and 11 years, one $(6.7 \%)$ between 12 and 14 years and one $(6.7 \%)$ for more than 15 years.

The Socio-Economic Brazilian Classification Criteria - $2000^{5}$ was used to evaluate the socio-economic conditions of the families. It showed that six (40\%) children belonged to class $\mathrm{C}$, with an average income of R\$ 927,00 (approximately US\$318.22), six (40.0\%) to class D, with an income of $\mathrm{R} \$ 424,00$ (approximately US\$ 145.50) and three (20.0\%) to class $\mathrm{E}$, with an income of $\mathrm{R} \$ 207.00$ (approximately US\$71.10) ( $p$ $=1.000)$.

Educational status of the head of the house was low: four $(26.7 \%)$ had not finished elementary school, $10(66.7 \%)$ finished elementary school and one $(6.6 \%)$ finished middle school.

Out of the infested children, six (40\%) resided in places without sewage infra-structure, seven $(46.7 \%)$ in wooden houses, five $(33.3 \%)$ in brick houses and three $(20 \%)$ half brick and wooden houses. Out of these, $14(93.3 \%)$ were owned by the families and one $(6.7 \%)$ rented. These 
houses were located on: four $(26.7 \%)$ on paved roads, four $(26.7 \%)$ on asphalted roads and seven $(46.4 \%)$ on gravel roads. Nine $(60 \%)$ children had pets (dogs being the majority).

\section{DISCUSSION}

Tungiasis can be considered as a neglected parasitic skin disease of public health importance ${ }^{24}$. In endemic tropical and subtropical areas, little or no significance has been given to this anthropozoonosis, which, besides causing pain, also may cause severe complications and even death $^{26}$. In high income countries, where occurrence is sporadic and most commonly diagnosed in travelers, diagnosis can be difficult for health professionals, because they are not familiar with this ectoparasitosis ${ }^{4,7}$.

In Latin America, this disease can be found from Mexico to Argentina ${ }^{18}$. In some regions of Latin America ${ }^{25}$, tungiasis is a common disease, which is usually treated at home by the person himself of by other members of the family. Tungiasis was first described in Brazil in 1649; although it is considered an endemic disease, few information is given about its occurrence.

In 1989, MATIAS ${ }^{33}$, in Rio Grande do Sul, Brazil, differently from previous findings, found tungiasis in the winter and rainy season, digging the grounds in orchards and flowerbeds. This author related the findings to the fact that in these seasons the parasite stays in the ground reducing its metabolism, in this case, when the parasite wakes up it starts its parasite activity furiously.

Even though in areas considered favorable to tungiasis occurrence, prevalence was $1.6 \%$, lower than those of $16 \%$ to $55 \%$ found in studies done by different authors such as ADE-SERRANO \& EJEZIE $^{1}$ and EJEZIE $^{12}$, in 1981, in Lagos, Nigeria; $\mathrm{ARENE}^{3}$, in 1984, in Choba, Nigeria; CHADEE', in 1994, in Trinidad, West of India; CHADEE $^{10}$, in 1998, also in Trinidad; CARVALHO et al. ${ }^{6}$, in 2003, in Araruama, Rio de Janeiro, Brazil; MATIAS ${ }^{33}$, in 1989, in Rio Grande do Sul, Brazil; WILCKE et ll $^{42}$, in 2002, and MUEHLEN et al. ${ }^{35}$, in 2003, in Fortaleza, Brazil.

The relatively low prevalence found in the present study occurred in the months of October, November and December of 2003, at the end of the dry season, different from the one of $4 \%$ found in the pilot study, which was developed in the month of April 2003, at the end of the rainy season. This fact may have happened because the pilot study was developed at the beginning of the school year. In this season, children return to school from the summer break and, according to school teachers, the parasitism is greater. The school teachers constantly monitor children for personal hygiene and send them to the appropriate healthcare services, if necessary. Maybe this fact explains the difference found between the occurrence of the parasite in these two different periods; when the field work was developed children were close to finish the school year and therefore had already been monitored and examined by the teacher and healthcare services respectively.

In this study, the prevalence was twice as high in female children as compared to males, but due to the low number of infested individuals, the difference was not statistically significant $(p=0.18)$. These results disagree from the ones found by ADE-SERRANO \& EJEZIE $^{1}$ and

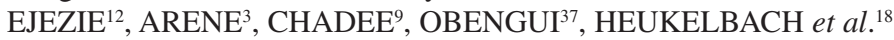

and WILCKE et al. ${ }^{42}$, where the number of males infested was higher.

The choice for the age range for this study was based on different authors such as ARENE $^{3}$, ADE-SERRANO \& EJEZIE ${ }^{1}$ and EJEZIE ${ }^{12}$, $\mathrm{OBENGUI}^{37}, \mathrm{CHADEE}^{9}, \mathrm{CHADEE}$ et al. ${ }^{8,10}$ and HEUKELBACH et al..$^{18}$. They believe that physical growth and consequently the keratinization of the skin, which functions as a natural barrier to the proteolytic enzymes, might make it difficult for the parasite to penetrate, therefore diminishing the occurrence of the disease. In this study, the prevalence was higher in the ages of eight and 10 years. However, there is no explanation for this occurrence since the behavior and socio-economic variables were the same in all age groups.

In the group of children we studied, the lesions caused by T. penetrans were found in the feet and around them, which were considered the most common areas for the parasite to penetrate and cause the disease. Other areas such as gluteal prominences, legs, knees, thighs, elbows and also the head have been related by FELDMEIER et al. ${ }^{15}$, CARVALHO et al. ${ }^{6}$ and HEUKELBACH et al..$^{22}$, and they were not found in this study.

In one child we observed a secondary bacterial infection, a common complication. The infection might have caused a translocation of normal micro-flora of skin of the child, with inflammation, ulcers and difficulty in walking.

Bacteriological studies about these findings have shown that aerobic and anaerobic ${ }^{13}$ microorganisms are present in these infections. With constant reoccurrence of the T. penetrans infestations, the risk of secondary bacterial infection grows, and severe infestations such as sepsis, gangrene, amputations and death might occur ${ }^{13,15}$.

Clostridium tetani might find in T. penetrans a helpful agent for its inoculation, which might cause tetanus in patients who are not vaccinated, as shows LITVOC et al. ${ }^{31}$, in 1991, in a study about tetanus in São Paulo, Brazil. Other authors such as OBENGUI ${ }^{37}, \mathrm{ARENE}^{3}, \mathrm{LINARDI}^{30}$ and MATIAS $^{33}$, have also related the occurrence of secondary bacterial infection and tetanus.

In our study, the majority of children infested with tungiasis studied or lived in pyritiferous soil areas. These areas were affected by coal disposal, which have sulfur, a myriad of metals and pyrites, among others. These areas lost economic values and were settled by low-income families. As FELDMEIER et al. ${ }^{15}$ observed in the slum of Morro de Sandras in Fortaleza, Ceará, northeast of Brazil, in Criciúma tungiasis is also associated with poverty. The houses built on the pyritiferous soil had no planning whatsoever and the occupation of public pieces of land has been done without the support of any infra-structure ${ }^{28}$.

The period children's families lived in these areas with tungiasis showed that $12(79.9 \%)$ of them resided in areas occupied recently in a disorganized manner and three $(20.1 \%)$ reside in such sites for more than nine years. This might have contributed to the dissemination of the T. penetrans in the region since the parasite might have been brought from other regions by the families.

The children infested with the parasite came from socially and economically underprivileged families and the years of schooling of those responsible for the household were low. This contributes to the 
Table 1

Individuals examined and prevalence of tungiasis in the study population, stratified by age, Criciúma, Santa Catarina State, Brazil, from October to December 2003

\begin{tabular}{lcccc}
\hline Age (years) & Examined & Positive & Prevalence $\%$ & $95 \%$ confidence interval \\
\hline 6 & 186 & 1 & 0.5 & $0.01-3.0$ \\
7 & 213 & 2 & 0.5 & $0.01-2.6$ \\
8 & 204 & 6 & $2.9 *$ & 0 \\
9 & 193 & 0 & $5.0^{*}$ & $1.1-6.3$ \\
10 & 121 & 6 & 1.9 & 1.9 \\
\hline Total & 917 & 15 & 0.5 & $0.92-2.68$ \\
\hline
\end{tabular}

$* p<0.001 ;$ reference group $=$ six years

disqualification of a person as a professional and his/her qualification for employment, thus contributing for low income and social exclusion. As a result, children do not seek medical assistance because the disease is not considered relevant and worthy to be looked at.

These observations agree with those of HEUKELBACH et al. ${ }^{18}$, that consider illiteracy, little schooling and poor hygiene conditions as factors that contribute to the dissemination of the parasite in the environment. They also agreed with those of WILCKE et al $^{42}$, who consider tungiasis a disease that spreads among underprivileged communities in Brazil. In addition, FELDMEIER et al. ${ }^{15}$ showed that tungiasis impacts the most underprivileged and neglected population without access to proper healthcare. JOSEPH et al. $^{26}$, observed in rural Haiti that community-based care can reduce tungiasis in extremely affected communities.

The sanitary conditions existing in areas where the children reside contributed to an epidemiological chain, which facilitated the dissemination of the disease. Domestic animals in these areas with poor hygiene conditions also contribute to the maintenance of the epidemiological chain in the region ${ }^{17}$. MUEHLEN et al. ${ }^{36}$, observed that both occurrence of tungiasis and heavy infestation were significantly linked to poor housing conditions, lack of health education and presence of animals on the compound.

Another form of transmission, less common than domestic animals, might occur through the soil fertilization or when chunks of lawn were brought from areas with high levels of contamination to places without contamination $^{33}$. This is another important aspect of Criciúma, since in areas containing pyrites for soil fertilization, large chunks of lawn brought from other locations had been placed locally.

In order to eradicate tungiasis, it is necessary to interrupt the epidemiological chain and the parasite's transmission ${ }^{25}$. The use of biological repellents, applied twice a day, brought up good results in combating tungiasis in endemic areas ${ }^{41}$.

In order to control the disease, MATIAS ${ }^{34}$, SANUSI et al. $^{40}$ and $\mathrm{CHADEE}^{10}$ recommend the use of chemical insecticides in external areas, where the flea is present. However, there is a need to treat domestic animals since they carry $T$. penetrans as shown by HEUKELBACH et $a l .{ }^{17}$ and ADE-SERRANO et al. ${ }^{2}$

\section{RESUMO}

\section{Tungíase em alunos da rede municipal de ensino em Criciúma, Santa Catarina, Brasil}

A tungíase é doença parasitária da pele, comum no Brasil, causada pela pulga Tunga penetrans. Realizamos estudo transversal para avaliar a ocorrência da infestação por T. penetrans em crianças, da pré-escola e do ensino fundamental de primeira à quarta série da rede municipal de ensino de Criciúma, Santa Catarina, Sul do Brasil. No total, 917 crianças (6 - 10 anos) de 68 escolas foram incluídas no estudo (11\% da população alvo). As crianças foram submetidas à inspeção física e nas com tungíase foi realizada visita domiciliar, para avaliar as condições da casa e para entrevista com o responsável legal da criança. Das 917, 15 (1,6\%) crianças estavam parasitadas. A prevalência do parasitismo foi duas vezes maior no sexo feminino (10 crianças - 2,2\%) que no masculino (cinco crianças - 1,1\%), mas pelo pequeno número de parasitados a diferença foi estatisticamente não significante $(p=0,18)$. A média aritmética das lesões encontradas foi de 1,4 por criança. Em uma criança foi observada infecção secundária bacteriana. Das 15 crianças parasitadas, $10(66,7 \%)$ estudavam em escolas construídas em solo piritoso. As famílias de 12 crianças parasitadas (79,9\%) residiam no local há menos de oito anos e foram consideradas famílias desfavorecidas, tendo o chefe da família baixa escolaridade. Concluímos que, em Criciúma, a tungíase ocorre em crianças da pré-escola e do ensino fundamental de primeira à quarta série da rede municipal de ensino, com baixa prevalência e carga parasitária.

\section{ACKNOWLEDGMENTS}

The authors thank to Professor Dr Reinaldo José Gianini, Department of Medicine of the Center for Biological and Medical Sciences of the Pontifícia Universidade Católica de São Paulo, researcher and Medical Research Laboratory 39 Hospital das Clínicas da Faculdade de Medicina da Universidade de São Paulo, by contributions in statistical analysis.

\section{REFERENCES}

1. ADE-SERRANO, M.A. \& EJEZIE, G.C. - Prevalence of tungiasis in Oto-Ijanikin village, Badagry, Lagos State, Nigeria. Ann. trop. Med. Parasit., 75: 471-472, 1981. 
2. ADE-SERRANO, M.A.; OLOMOLEHIN, O.G. \& ADEWUMMI, A. - Treatment of human tungiasis with niridazole (Ambilhar) a double-blind placebo-controlled trial. Ann. trop. Med. Parasit., 76: 89-92, 1982.

3. ARENE, F.O. - The prevalence of sand flea (Tunga penetrans) among primary and postprimary school pupils in Choba area of the Niger Delta. Publ. Hith (Lond.), 98 282-283, 1984.

4. BAUER, J.; FORSCHNER, A.; GARBE, C. \& RÖCKEN, M. - Dermatoscopy of tungiasis Arch. Derm., 140: 761-763, 2004

5. BRASIL - Critério de Classificação Econômica Brasil. (accessed February 12, 2003). http:/www.somatório.com/criteriobrasil.asp

6. CARVALHO, R.W.; ALMEIDA, A.B.; BARBOSA-SILVA, S.C. et al. - The patterns of tungiasis in Araruama township, State of Rio de Janeiro, Brazil. Mem. Inst. Oswaldo Cruz, 98: 31-36, 2003

7. CAUMES, E.; CARRIERE, J.; GUERMONPREZ, G. et al. - Dermatoses associated with travel to tropical countries: a prospective study of the diagnosis and management of 269 patients presenting to a tropical disease unit. Clin. infect. Dis., 20: 542-548, 1995.

8. CHADEE, D.D.; FURLONGE, E.; NARAYNSINGH, C. \& LEMAITRE, A. - Distribution and prevalence of Tunga penetrans in coastal south Trinidad, West Indies. Trans. roy. Soc. trop. Med. Hyg., 85: 549, 1991.

9. CHADEE, D.D. - Distribution patterns of Tunga penetrans within a community in Trinidad, West Indies. J. trop. Med. Hyg., 97: 167-170, 1994.

10. CHADEE, D.D. - Tungiasis among five communities in south-western Trinidad, West Indies. Ann. trop. Med. Parasit., 92: 107-113, 1998.

11. EISELE, M.; HEUKELBACH, J.; MARCK, E.V. et al. - Investigations on the biology, epidemiology, pathology and control of Tunga penetrans in Brazil: I. Natural history of tungiasis in man. Parasit. Res., 90: 87-99, 2003.

12. EJEZIE, G.C. - The parasitic diseases of school children in Lagos State, Nigeria. Acta trop. (Basel), 38: 79-84, 1981.

13. FELDMEIER, H.; HEUKELBACH, J.; EISELE, M. et al. - Bacterial superinfection in human Tungiasis. Trop. Med. int. HIth, 7: 559-564, 2002.

14. FELDMEIER, H.; HEUKELBACH, J.; EISELE, M. et al. - Investigations on the biology, epidemiology, pathology and control of Tunga penetrans in Brazil: III. Cytokine levels in peripheral blood of infected humans. Parasit. Res., 91: 298-303, 2003.

15. FELDMEIER, H.; EISELE, M.; SABÓIA-MOURA, R.C. \& HEUKELBACH, J. - Severe tungiasis in underprivileged communities: case series from Brazil. Emerg. infect. Dis., 9: 949-955, 2003.

16. FELDMEIER, H.; KEHR, J.D. \& HEUKELBACH, J. - A plant-based repellent protects against Tunga penetrans infestation and sand flea disease. Acta trop., 99: 126-136, 2006

17. HEUKELBACH, J.; COSTA, A.L.M.; WILCKE, T.; MENCKE, N. \& FELDMEIER, H. - The animal reservoir of Tunga penetrans in poor communites in Northeast Brazil. Med. vet. Entomol., 18: 329-335, 2004.

18. HEUKELBACH, J.; DE OLIVEIRA, F.A.S.; HESSE, G. \& FELDMEIER, H. - Tungiasis: a neglected health problem of poor communities. Trop. Med. int. Hlth., 6: 267-272, 2001

19. HEUKELBACH, J.; EISELE, M.; JACKSON, A. \& FELDMEIER, H. - Topical treatment of tungiasis: a randomized, controlled trial. Ann. trop. Med. Parasit., 97: 743-749, 2003.

20. HEUKELBACH, J.; FRANCK, S. \& FELDMEIER, H. - High attack rate of Tunga penetrans (Linnaeus, 1758) infestation in an impoverished Brazilian community. Trans. roy. Soc. trop. Med. Hyg., 98: 431-434, 2004.
21. HEUKELBACH, J.; FRANCK, S. \& FELDMEIER, H. - Therapy of tungiasis: a doubleblinded randomized controlled trial with oral ivermectin. Mem. Inst. Oswaldo Cruz, 99: 873-876, 2004.

22. HEUKELBACH, J.; WILCKE, T.; EISELE, M. \& FELDMEIER, H. - Ectopic localization of Tungiasis. Amer. J. trop. Med. Hyg., 67: 214-216, 2002

23. HEUKELBACH, J.; WILCKE, T.; WILCKE, T.; HARMS, G. \&, FELDMEIER, H. Seasonal variation of tungiasis in an endemic community. Amer. J. trop. Med. Hyg., 72: $145-149,2005$.

24. HEUKELBACH, J. - Tungiasis. Rev. Inst. Med. trop. S. Paulo, 47: 307-313, 2005.

25. HEUKELBACH, J. - Revision on tungiasis: treatment options and prevention. Expert. Rev. Anti infect. Ther., 4: 151-157, 2006.

26. JOSEPH, J.K.; BAZILE, J.; MUTTER, J. et al. - Tungiasis in rural Haiti: a communitybased response. Trans. roy. Soc. trop. Med. Hyg., 100: 970-974, 2006.

27. KREBS, A.S.J.; DIAS, A.A. \& VIERO, A.C. - Áreas mineradas para carvão no município de Criciúma, SC. 2. ed. Porto Alegre, CPRM, 1994.

28. KREBS, A.S.J.; SEARA, L.F.R.; BORTOT, A. \& VIERO, A.C. - Situação legal das áreas mineradas no município de Criciúma, SC. Porto Alegre, CPRM, 1995.

29. LINARDI, P.M. - Siphonaptera. In: NEVES, D.P. Parasitologia humana. 10. ed. São Paulo, Atheneu, 2000. p. 359-364

30. LINARDI, P.M. - Pulgas. In: MARCONDES, C.B. Entomologia médica e veterinária São Paulo, Atheneu, 2001. p. 157-179.

31. LITVOC, J.; LEITE, R.M. \& KATZ, G. - Aspectos epidemiológicos do tétano no Estado de São Paulo (Brasil), 1989. Rev. Inst. Med. trop. S. Paulo, 33: 477-484, 1991.

32. MARCONDES, C.B. - Entomologia médica e veterinária. São Paulo, Atheneu, 2001. p. 177

33. MATIAS, R.S. - Epidemia de tungíase no Rio Grande do Sul. Rev. Soc. bras. Med. trop., 22: 137-142, 1989.

34. MATIAS, R.S. - Verificação da eficácia de diferentes inseticidas no controle ambienta de Tunga penetrans. Rev. Soc. bras. Med. trop., 24: 31-36, 1991.

35. MUEHLEN, M.; HEUKELBACH, J.; WILCKE, T. et al. - Investigations on the biology, epidemiology, pathology and control of Tunga penetrans in Brazil. II. Prevalence, parasite load and topographic distribution of lesions in the population of a traditional fishing village. Parasit. Res., 90: 449-455, 2003

36. MUEHLEN, M.; FELDMEIER, H.; WILCKE, T.; WINTER, B. \& HEUKELBACH J. - Identifying risk factors for tungiasis and heavy infestation in a resource-poo community in northeast Brazil. Trans. roy. Soc. trop. Med. Hyg., 100: 371-380, 2006

37. OBENGUI. - La tungose et le tétano au C.H.U. de Brazzaville. Dakar méd., 34: 44-48, 1989

38. PAMPIGLIONE, S.; TRENTINI, M.; FIORAVANTI, M.L.; ONORE, G. \& RIVASI, F. - On a new species of sand flea from Ecuador and tungiasis, a problem of public health in many developing countries. Ann. Igiene, 15: 747-752, 2003.

39. PILGER, D.; SCHWALFENBERG, S.; HEUKELBACH, J. et al. - Investigations on the biology, epidemiology, pathology, and control of Tunga penetrans in Brazil: VII. The importance of animal reservoirs for human infestation. Parasit. Res., 102: 875-880, 2008 .

40. SANUSI, I.D.; BROWN, E.B.; SHEPARD, T.G. \& GRAFTON, W.D. -Tungiasis: report of one case and review of the 14 reported cases in the United States. J. Amer. Acad. Derm., 20: 941-944, 1989. 
41. SCHWALFENBERG, S.; WITT, L.H.; KEHR, J.D.; FELDMEIER, H. \& HEUKELBACH, J. - Prevention of tungiasis using a biological repellent: a small case series. Ann. trop. Med. Parasit., 98: 89-94, 2004
42. WILCKE, T.; HEUKELBACH, J.; MOURA, R.C.S.; KERR-PONTES, L.R.S. \& FELDMEIER, H. - High prevalence of Tungiasis in a poor neighbourhood in Fortaleza, Northeast Brazil. Acta trop., 83: 255-258, 2002.

Received: 27 October 2006

Accepted: 16 January 2009 